\title{
MAMMAL FAUNA OF CHISINAU AIRPORT, REPUBLIC OF MOLDOVA
}

\author{
Victoria NISTREANU, Alina LARION \\ Institute of Zoology, Chisinau, Republic of Moldova
}

Corresponding author: Victoria Nistreanu, e-mail: vicnistreanu@gmail.com

DOI: $10.38045 /$ ohrm.2022.1.07

CZU: 599:651.71(478-25)

Keywords: Chisinau airport, mammals, rodents, abundance, fox, trophic connections.
Cuvinte cheie: aeroportul Chișinău, mamifere, rozătoare, abundență, vulpe, conexiuni trofice.
Introduction. Airport territories are large, containing a high variety of biotopes, mostly open type, and are relatively protected against intense human activity, thus creating favorable conditions for many mammal species that serve as trophic source for many bird species. Material and methods. The studies were performed during 2012-2014 on the territory of Chisinau airport and within the adjacent ecosystems. The mammals were recorded by direct observations, based on traces and trophic activity on routes ranging from 1 to $3 \mathrm{~km}$. The small mammals were assessed with traps. The bat species were identified according to their flight pattern and using the ultrasound detector.

Results. In the airport, 31 species of mammals were registered: 5 insectivore species, 7 bat species, 14 rodent species, 1 hare species and 4 carnivorous species. The most widespread, common and abundant were the rodents and the fox. Among small rodent species, the most abundant was Apodemus sylvaticus with 51.6\%, followed by the Microtus arvalis (38.9\%), while on the airport grassland, the field vole dominated with more than $60 \%$. The diet of Athene noctua included predominantly Mus musculus with over 51\%, followed by M. arvalis with $23.7 \% .7$ species are rare and 5 protected - bicolor shrew and 4 bat species.

Conclusions. The airport territory and adjacent ecosystems provide favorable conditions for many mammal species. The presence of rodents favors the occurrence of rather high number of prey birds, which represent a threat for the safety of aircraft flights. The fox can pose direct threat to flight safety.

\section{FAUNA DE MAMIFERE DIN AEROPORTUL CHIȘINĂU, REPUBLICA MOLDOVA}

Introducere. Teritoriile aeroporturilor sunt extinse, conțin multe biotopuri, majoritatea de tip deschis, fiind relativ protejate de activitățile umane intense, creând astfel condiții favorabile pentru mamiferele care pot servi drept sursă trofică pentru păsările de pradă.

Material și metode. Cercetările au fost efectuate în 2012-2014, pe teritoriul aeroportului Chișinău și în ecosistemele adiacente. Mamiferele au fost înregistrate prin observații directe, după urme și activitate trofică, pe trasee de 1-3 km. Mamiferele mici au fost evaluate cu ajutorul capcanelor, iar liliecii au fost identificați după particularitățile de zbor și cu detectorul de ultrasunete.

Rezultate. În aeroport au fost înregistrate 31 specii de mamifere: 5 specii insectivore, 7 specii de lilieci, 14 specii de rozătoare, 1 specie de iepuri și 4 specii de carnivore. Cele mai răspândite și prolifice au fost rozătoarele și vulpea. Dintre rozătoare, cea mai frecvent atestată a fost Apodemus sylvaticus - 51,6\%, urmată de Microtus arvalis (38,9\%), iar pe pajiștea din aeroport a dominat șoarecele de câmp cu peste 60\%. În rația Athene noctua dominant a fost Mus musculus, cu peste 51\%, urmat de M. arvalis cu 23,7\%. Au fost semnalate 7 specii rare și 5 specii protejate - chițcanul de câmp și 4 specii de lilieci.

Concluzii. Teritoriul aeroportului și ecosistemele adiacente oferă condiții favorabile pentru multe specii de mamifere. Prezența rozătoarelor favorizează atragerea păsărilor de pradă, care reprezintă o amenințare pentru siguranța zborurilor. Vulpea, la rândul ei, poate periclita siguranța zborurilor. 


\section{INTRODUCTION}

The territories of the airports are spacious, including many different biotopes, mainly of open type, and are protected from visiting by people, thus creating favorable conditions for the existence of a large number of bird species, as well as mammals, reptiles, amphibians, and insects that serve as trophic source for many terrestrial vertebrate species. The animals are attracted by the abundance of food resources, low anxiety factor, the availability of places for food, rest, shelter and breeding. The presence of vertebrate species, especially of birds, on the airport territories can cause serious problems to aviation. Wildlife aircraft collisions cause losses of human lives and financial losses for the aviation industry (1).

Although bird species are the main risk factor for aircraft safety, many other terrestrial vertebrate species can present direct or indirect threat to aviation. The large and medium-sized mammal species are a potential risk for aircraft flights, such as deer, red deer, fox, coyote, hare $(2,3,4)$. The rodent species have an indirect impact, being the main prey for many vertebrate predator species. In many parts of the world, regulating the number of mammals, especially rodents at airports, is a serious problem $(5,6,7,8)$.
The purpose of the study was to assess the mammal fauna in Chisinau airport and adjacent territories in order to reveal its diversity and the species that can have a direct or indirect impact upon aircraft flight, as well as the rare species occurring in the area.

\section{MATERIAL AND METHODS}

The Chisinau airport is situated at the altitude of $122 \mathrm{~m}$, with coordinates $46^{0} 55^{\prime} 40^{\prime \prime} \mathrm{N} 28^{0} 55^{\prime} 51^{\prime \prime} \mathrm{E}$ in the eastern part of the city, extending on a surface of $4271 \mathrm{~m}^{2}$. The studies were performed during 2012-2014 on the territory of Chisinau airport and adjacent ecosystems. Within the airport, biotopes are represented by grasslands (mowed and unmowed), sectors with shrub vegetation and sectors with different types of technical buildings, including abandoned ones, tree vegetation near the buildings and several small water basins for technical purpose (fig.1). The adjacent biotopes are represented by various agroecosystems (orchards, vineyards, corn, sunflower and cereals), private gardens, sectors with buildings, forest belt, grasslands, fallow ground, wet habitats, as well as ecotones that create convenient transition zones to the airport many vertebrate animal species.

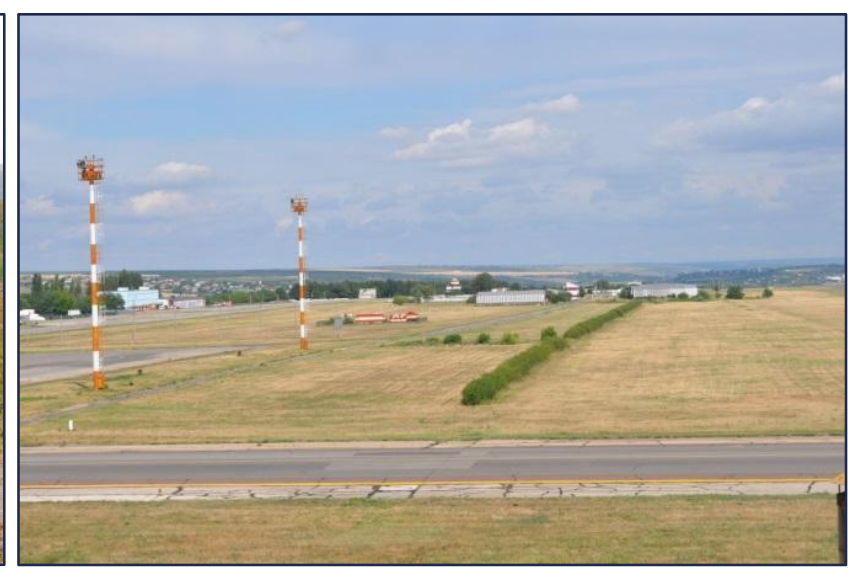

Figure 1. Open type biotopes in Chisinau airport.

The mammals were recorded by direct observations, according to the traces and trophic activity (carnivorous mammals) on routes ranging from 1 to $3 \mathrm{~km}$. The small mammals were assessed with traps; 7,000 trap-nights were used and more than 300 animals were caught. The density of subterranean mammal species (mole and mole rat) was determined by direct observations and by count- ing the molehills. The density of the hedgehog was determined by direct observation during activity hours and by the presence of trophic remains. The registration of bats was carried out in the evening by identifying species after the flight pattern and using the ultrasound detector.

The density of medium-sized mammals was assessed as individuals per hectare. In the commu- 
nities of bats and small mammals (shrews and rodents) the relative abundance of each species was determined.

Pellets of the little owl (Athene noctua) were collected from an abandoned building situated in the central part of the airport. Each pellet was measured, weighed and afterwards unfolded. The bone fragments were cleaned and sorted into categories. Small mammal species were determined according to cranial bones and dentition $(9,10)$.

\section{RESULTS}

The mammal fauna of Chisinau airport was represented by 31 species - 5 insectivore, 7 bat, 14 rodent, 1 lagomorph, 4 carnivorous species (tab. 1).

Among insectivorous mammals, represented by 5 species, 3 species were found both on the airport territory and within the adjacent ecosystems. The white-breasted hedgehog was observed in the spring-autumn period in the evening hours with a density of $0.3-1$ ind./ha in the airport and about 1-2 ind./ha in adjacent biotopes. Mole density varied from 1 to 2 ind./ha and reached 4 ind./ha in optimal adjacent habitats.

The lesser white-toothed shrew (Crocidura suaveolens) is the most anthropophilous species among shrews and was often found in most ecosystems, including buildings, whose abundance constituted about $2 \%$ of the community of small mammals. The common and bicolor whitetoothed shrews were found only in wet biotopes adjacent to the airport (banks of ponds, rivers, swampy habitats) with an abundance of $0.7-1 \%$.

Table 1. Fauna of mammals on Chisinau airport and adjacent biotopes.

\begin{tabular}{|c|c|c|c|c|}
\hline \multirow{2}{*}{ No } & \multirow[t]{2}{*}{ Species } & \multicolumn{2}{|c|}{ Density/abundance } & \multirow[t]{2}{*}{ Status } \\
\hline & & Airport territory & Adjacent biotopes & \\
\hline \multicolumn{5}{|c|}{ Mammalia } \\
\hline 1. & Erinaceus roumanicus & 1 ind./ha & 2 ind./ha & Common \\
\hline 2. & Talpa europaea & 1-2 ind./ha & $2-4$ ind./ha & Common \\
\hline 3. & Sorex araneus & - & $0.7 \%$ & Rare \\
\hline 4. & Crocidura leucodon & - & $1.0 \%$ & VU \\
\hline 5. & Crocidura suaveolens & $0.8 \%$ & $1.2 \%$ & Common \\
\hline 6. & Myotis daubentonii & - & $9.3 \%$ & VU \\
\hline 7. & Myotis mystacinus & $1.2 \%$ & $3.1 \%$ & $\mathrm{VU}$ \\
\hline 8. & Nyctalus noctula & $45.9 \%$ & $38.2 \%$ & Common \\
\hline 9. & Pipistrellus pygmaeus & $17.6 \%$ & $12.8 \%$ & Common \\
\hline 10. & Eptesicus serotinus & $32.7 \%$ & $26.7 \%$ & Common \\
\hline 11. & Vespertilio murinus & - & $3.8 \%$ & EN \\
\hline 12. & Plecotus austriacus & $2.6 \%$ & $6.1 \%$ & VU \\
\hline 13. & Nannospalax leucodon & 1-2 ind./ha & 2-4 ind./ha & Common \\
\hline 14. & Muscardinus avellanarius & - & $0-2$ ind./ha & Rare \\
\hline 15. & Sciurus vulgaris & 1 ind./ha & $2-3$ ind./ha & Common \\
\hline 16. & Arvicola terrestris & - & 2-10 ind./ha & Rare \\
\hline 17. & Rattus norvegicus & 1 ind./ha & $1-2$ ind./ha & Common \\
\hline 18. & Mus musculus & $2.9 \%$ & $24.7 \%$ & Abundant \\
\hline 19. & Mus spicilegus & $1.9 \%$ & $8.4 \%$ & Common \\
\hline 20. & Apodemus sylvaticus & $51.6 \%$ & $40.2 \%$ & Abundant \\
\hline 21. & Apodemus agrarius & - & $3.5 \%$ & Common \\
\hline 22. & Apodemus uralensis & $3.9 \%$ & $8.1 \%$ & Common \\
\hline 23. & Apodemus flavicollis & - & $1.6 \%$ & Common \\
\hline 24. & Clethrionomys glareolus & - & $1.1 \%$ & Common \\
\hline 25. & Microtus arvalis & $38.9 \%$ & $9.2 \%$ & Abundant \\
\hline 26. & Microtus rossiaemeridionalis & - & $3.2 \%$ & Common \\
\hline 27. & Lepus europaeus & 3 ind./1000 ha & 2-4 ind./1000 ha & Common \\
\hline 28. & Vulpes vulpes & 6 ind./1000 ha & 18 ind./1000 ha & Abundant \\
\hline 29. & Mustela nivalis & 2 ind./1000 ha & $1-2$ ind./1000 ha & Rare \\
\hline 30. & Mustela putorius & - & $1-2$ ind./1000 ha & Rare \\
\hline 31. & Martes foina & - & $1-2$ ind./1000 ha & Rare \\
\hline
\end{tabular}


During the study period 7 bat species were registered: Daubenton's bat (Myotis daubentonii), whiskered bat (M. mystacinus), common noctule (Nyctalus noctula), soprano pipistrelle (Pipistrellus pygmaeus), serotine bat (Eptesicus serotinus), parti-colored bat (Vespertilio murinus) and grey long-eared bat (Plecotus austriacus). The most abundant were the common noctule and the serotine bat that constituted more than $70 \%$ on airport territory and over $60 \%$ in adjacent ecosystems. Both species are well adapted to anthropic environment, use for hibernation, reproduction and shelter various types of buildings and hunt insects in open biotopes. The soprano pipistrelle is also well adapted to urban environment, hibernating in large colonies, breeding in buildings and hunting for insects in open areas. The Daubenton's bat was registered near the water basins outside the airport area. Other bat species were recorded in small number and were observed in the buildings near the airport, where they find shelter in the attics, cracks in the walls, empty spaces of balconies etc.

The rodent fauna was most well represented, with 14 species on airport territory and in adjacent ecosystems (tab. 1). The mole rat was registered all over the studied territory with the density of 1-2 ind./ha on the territory and of 2-3 ind./ha in surroundings. Tree associations present in small amount on the airport territory and rather abundant in adjacent areas create favorable conditions for squirrel and hazel dormouse, the last one being rarely recorded only in adjacent arboreous vegetation. The synanthropic species $R$. norvegicus and $M$. musculus were registered near various buildings and water basins from the airport territory with more intense anthropic activity and accumulation of household waste. The species Microtus rossiaemeridionalis was registered in black locust stands outside airport territory.

The dominant species the small rodent community at the airport was the wood mouse (A. sylvaticus) with more than $50 \%$, registered mostly near the perimeter and in bush vegetation. It is a eurytopic species that inhabit both forest and open ecosystems, well adapted to the anthropogenic landscape. The field vole constituted about 39\% in trap assessment, however numerous colonies were found in grassland biotopes with an average density of 10-15 col./ha (up to $25 \mathrm{col}$./ ha near the perimeter and 5-6 col./ha in the central part of the airport). A. uralensis registered $4 \%$, followed by the Mus species, of which M. musculus (2.9\%) was caught near the buildings and M. spicilegus $(1.9 \%)$ near the perimeter, limiting with agrocoenoses, where its mounds were observed.

The biotopic distribution of the most abundant small rodent species was assessed in the airport grassland and in the adjacent biotopes (fig. 2). In grassland the dominant species was $M$. arvalis with over $60 \%$, followed by A. sylvaticus with

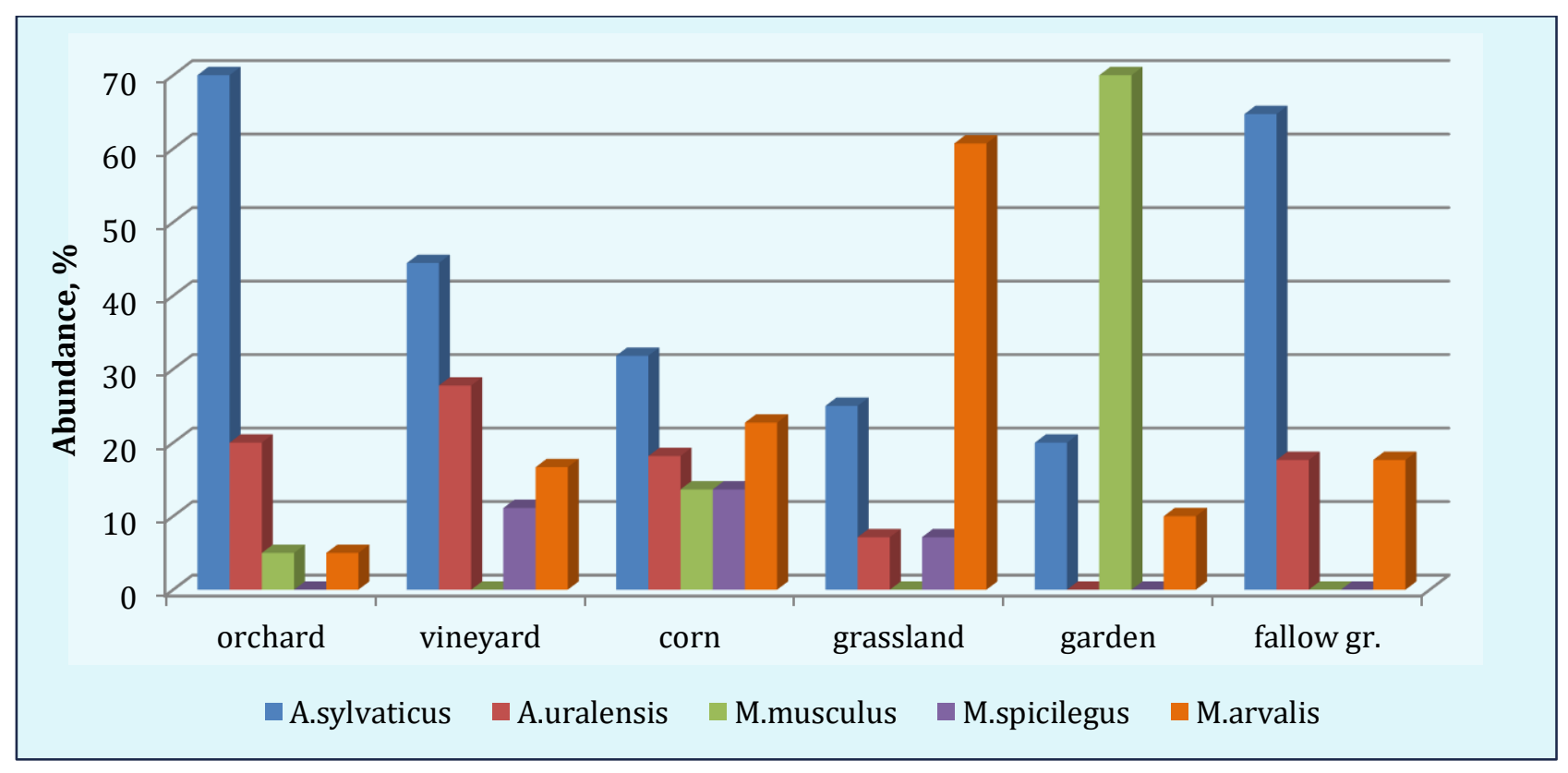

Figure 2. Biotopic distribution of the main small rodent species in airport and in adjacent biotopes. 
$25 \%$, while other species had a low abundance. In the adjacent biotopes (orchard, vineyard, corn and fallow ground) the dominant species was $A$. sylvaticus, with more that $60 \%$ in orchard and fallow ground. The most even species distribution was registered in cornfield, where all 5 species were found. In people's gardens the house mouse dominated with $70 \%$, while other 2 recorded species had much lower abundance.

The presence of cultivated lands adjacent to the airport with various crops, such as corn, sunflower, alfalfa, cereals, vineyards, orchards, as well as fallow ground is favorable for the rodent species. The presence of different buildings, waste at the airport, as well as the proximity of settlements create favorable conditions for the synanthropic species - house mouse and brown rat. Wood associations represented by decorative trees, rows of trees, forest belts, forest parks are present in small numbers at the airport and abundantly in the surrounding areas, thus creating favorable conditions for squirrels, dormouse, yellow-necked mouse and bank vole. In the humid habitats adjacent to the airport the water vole and the brown rat were recorded.

The European hare was observed several times in the sectors adjacent to the airport in fallow ground, orchards and vineyards, where this species finds favorable trophic and shelter conditions. It enters the airport through the holes under the fence, where it feeds on grassy vegetation, and the low disturbance factor is favorable. During the study period, the remnants of some hares (3 individuals) were observed not far from the runway, probably eaten by fox.

The carnivorous mammals were represented by 4 species: fox, weasel, polecat and stone marten, of which 2 species (fox and weasel) were observed on the airport territory. The weasel was observed only once in the south-eastern part, near the closest locality, and its excrements were found several times during counting routes along the southern perimeter of the airport. The fox was the most numerous and its density was of 6 ind./ha in the airport and about 20 ind./ha in adjacent biotopes (tab. 1). Traces of the fox trophic activity (hare and chicken carcasses) were found at $25-30 \mathrm{~m}$ from the runway in the south-eastern and southern parts of the airport, near to cultivated lands and to the localities. Even after catching the prey in the nearest ecosystems, the fox prefers to eat it in the airport area, where there is a low level of disturbance and easy access ways.

The polecat (M. putorius) and the stone marten (M. foina) and their activity traces were seldom observed outside of the airport area in the eastern and southern parts, closer to the localities. They often inhabit rural environment and are considered anthropophilous species.

The hare and carnivorous mammals were crossing easily the perimeter of the airport due to the unpropper installation of the fence at a height of 5-10 cm from the ground level. During the summer period of 2013, several dozen holes were found under the fence along the perimeter of the airport, mainly in its western and northwestern parts. On a perimeter section of about $500 \mathrm{~m}$ along the fence 12 old holes and 7 freshly dug ones were counted. The holes were regularly covered with earth by airport workers, but new ones appeared in the next few days. The holes were dug by the fox, but the hare and the weasel also used them to pass on the airport territory.

In the western part of the airport, mounds of sand and gravel were found, with a height of 1-1.5 m, surrounded by dense and high ruderal vegetation. In these embankments, fox burrows with several entrances were found, with many trophic remnants and excrement nearby (fig. 3). Also, in the south-western part, close to a fallow ground, other fox burrows were observed.

In an abandoned building from the central part of the airport little owl (Athene noctua) pellets were found. It is a sedentary species that use for food a large number of rodents in the autumn-winter period. Its presence on the territory is due to a low disturbance factor, the abundance of food objects and the presence of abandoned buildings. The analysis of pellets revealed that the trophic spectrum of the owl in the autumn-winter period consists mainly of small rodents and of insects (fig. 4).

The dominant species in little owl's diet was the house mouse, due to its rather high abundance on the airport territory and adjacent localities. The second preferred prey was the field vole with about $24 \%$, followed by insects with $17 \%$. The Apodemus genus species were found in low proportion.

Among the mammals registered on the airport territory and adjacent ecosystems most of the species were common or numerous, especially 

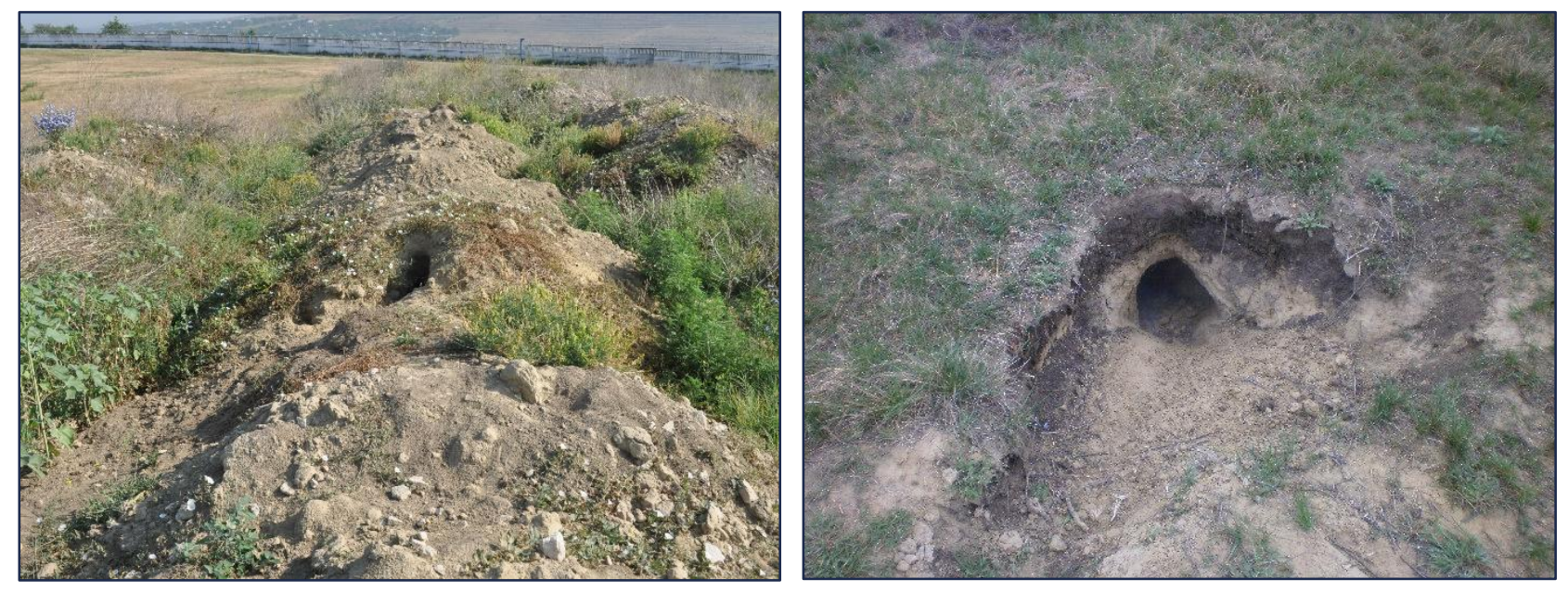

Figure 3. Mounds of sand and gravel with several fox burrows and a fox burrow in the south-western part of the airport.

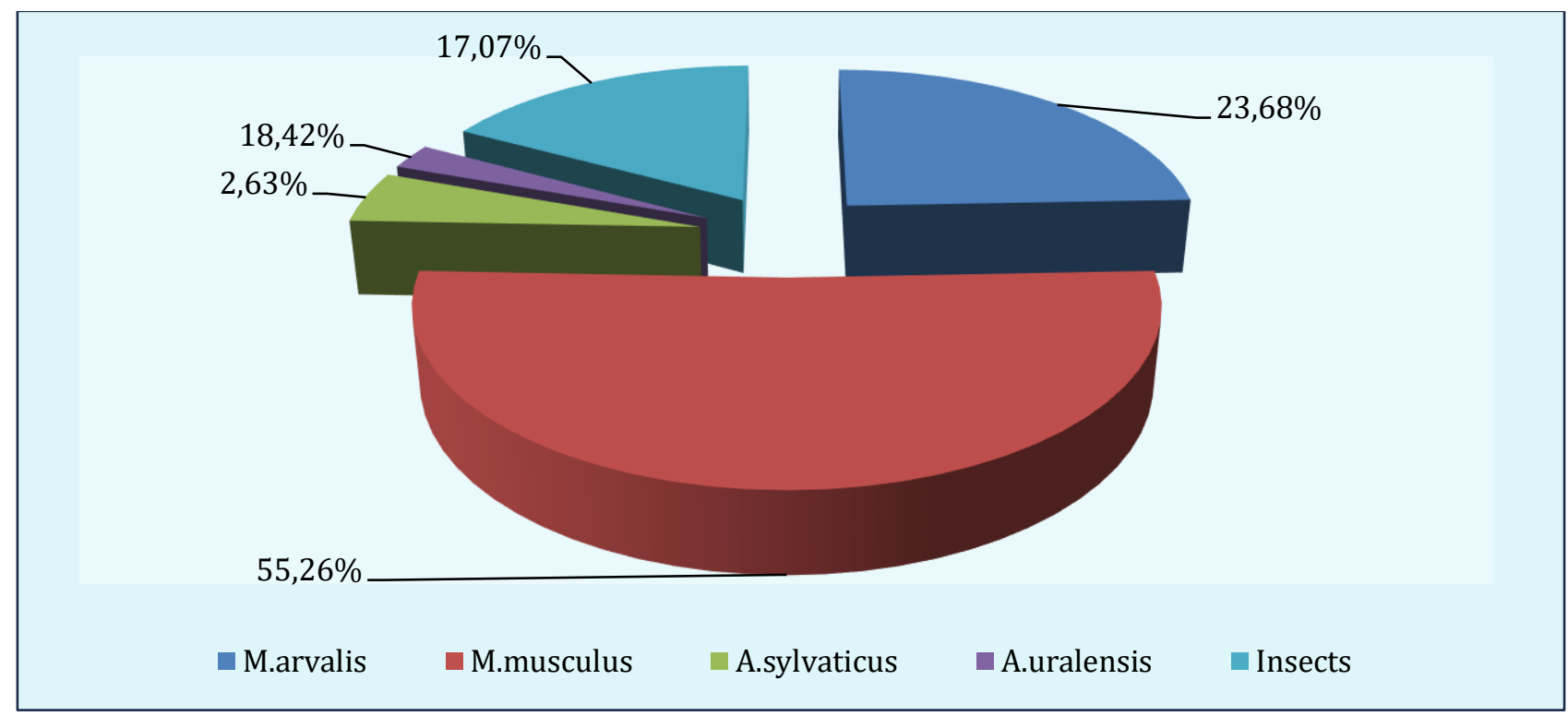

Figure 4. Trophic spectrum of $A$. noctua in the Chisinau airport.

the small rodents and the fox. 7 rare and 5 species listed in the Red Book of the Republic of Moldova were registered - Crocidura leucodon, Myotis daubentonii, M. mystacinus, Vespertilio murinus and Plecotus austriacus (11).

\section{DISCUSSIONS}

The increasing trend of wildlife strikes recorded worldwide in recent years poses a serious threat to air traffic safety (12). Among the factors responsible for this trend is the air traffic increase on a global scale, but also other factors may contribute to this increase, such as larger populations of synanthropic species or the presence of attractive sites near airports, such as landfills and fish culture ponds (1). In the case of Chisinau airport, the adjacent sites are represented by various types of agricultural ecosystems, forest belts and parks that are attractive for many vertebrate species. Besides, over the last years large populations of mammal species have adapted to anthropic environment, which led to the increased activity of wildlife within urban settlements. Therefore, in the last decades in urban ecosystems of Chisinau city there were registered 7 insectivore species (13), 11 bat species (14), 16 rodent species and 5 carnivorous species $(15,16)$. Among carnivorous mammals the fox shows an increased adaptive potential for anthropogenic conditions and was frequently recorded in localities, including Chisinau city and the suburbs, where it finds favorable shelter and trophic conditions (17). 
About $97 \%$ of wildlife strikes to aircraft occur with bird species, but researchers have established that terrestrial mammals and even reptiles can pose a significant risk due to their size and weight $(2,18,19)$. Although, terrestrial mammals represent only $2.3 \%$ of wildlife incidents, $59 \%$ of these incidents caused damage to aircraft and almost half of the planes destroyed in wildlife incidents from 1990 to 2010 were damaged by mammals (18).

Most collisions with terrestrial mammals occur inside the airport, usually with species that normally benefit from buildings, airport structures, or the local environment. Cases of aircraft strikes with bats were not registered in Chisinau airport and bat strikes are currently considered to be a low proportion of all wildlife collisions. However, in the United States, bat strike reports have steadily increased from 4 in 1990 to a total of 255 in 2014 (18), while in some regions of Europe the estimated rate of bat collisions with aircraft is low (20).

The most serious hazard posed by small sized mammal species, especially by rodent population at airports, is the indirect risk of attracting predatory vertebrates. The rodents are the most common and eurytopic species among mammals and they serve as a food source for many species of birds of prey, carnivorous mammals and reptiles, representing an important link in the trophic chains of the living world. Among predatory groups, the prey birds pose one of the most hazardous groups of birds at the airport setting (21). In the last decades birds are considered as a threat for aircraft flights, due to increased traffic and rather high number of collisions that lead to numerous accidents (22). The aircraft size and speed increased, the noise produced by the engines decreased, thus it became more difficult for the birds to coordinate their flight, to timely detect the approach of aircraft and to avoid collision.

In the study period prey birds were often observed on the airport territory, even on the runway and on various heights (in the perimeter fence, on various buildings, on pillars) waiting for their preferred prey - the rodents. Among prey bird species the common buzzard (Buteo buteo), the common kestrel (Falco tinnunculus), the sparrowhawk (Accipiter nisus) and the little owl (Athene noctua) were registered more frequent. For most of them the main trophic objects are the rodents, especially the filed vole, which exhibit multi-year cycles and reach population peaks every 3-5 years. Many prey birds are attracted to areas such as airports during the peaks of these population cycles (5).

For the nocturnal prey birds, the Microtus voles are usually the preferred prey, but in the diet of little owl a high proportion constitute the insects and other invertebrates (23 - 28). The contribution to the main prey categories of little owl diet usually vary seasonally, in the spring-autumn period invertebrates were more frequently preyed, while the rodents dominated in winter $(29,30)$. In Chisinau airport, the main rodent prey of $A$. noctua was the house mouse, due to highly anthropized territory and proximity of localities.

One of the most important myophagous (mouse eating) mammal species is the fox, frequently recorded in the airport. It is an eurytopic species, which has increased number in various types of ecosystems, including localities. In 2008-2015 the density of the fox was extremely high and exceeded the ecological norm of about 10 times, being registered with an abundance of 18-21 ind./1000 ha in various ecosystems of the republic (17). The fox finds favorable living conditions on agrocoenoses adjacent to the airport (gardens, corn, fallow ground), enters the territory in search of food and because of the low anthropogenic disturbance. Bodies of water and natural vegetation present in airport vicinity can act as a refuge for foxes $(2,3)$. Several times during winter, the airport staff observed the fox running to the runway immediately before the take-off or after the landing of the planes, where it lied down on still warm runway.

At the end of the 2-year period of airport fauna monitoring several measures were recommended in order to reduce the density and abundance of mammal species that pose a risk for aircraft safety:

- Regular perimeter control. Burying the fence around the airport perimeter $10-15 \mathrm{~cm}$ into the ground or building a concrete foundation.

- Removal of existing sand, gravel or earth mounds, removal of various embankments and avoid waste accumulations.

- Installation of gratings in all hatches, drain pipes and channels leading outside the perimeter of the airport. 
- Periodic mowing of the grass cover throughout the territory, the optimal height is $5-10 \mathrm{~cm}$.

-When possible, removal of shrubs and ornamental trees.

- Removal of unused buildings, periodic control of attics, collecting of bats and owls that breed and/or spent the winter there and their release outside the airport territory (since these are useful and sometimes rare species).

- Annual availability of a forecast of the rodent number; periodic treatment with rodenticides, mandatory in the spring and autumn periods, and in the peak years up to 4 times a year.

- Regular monitoring of the entire territory to detect fox burrows and their destruction, burying the holes under the perimeter fence.

- Periodic treatment with insecticides in spring and summer periods to avoid insect breeding that attract bats and birds.
- Avoiding cereal grain cultivation in the adjacent to the airport sectors as these crops are attractive for rodents as well as for grain-eating birds.

Following our recommendations, the holes under the fence were regularly covered with soil by the airport workers, new holes appeared more and more rare and by the end of 2014 their number decreased significantly. Also, after the removal of soil and sand mounds no more fox activity was registered in the sector.

Aircraft - wildlife strikes present a global issue requiring both a local and global analytical perspective. Regional characteristics must be considered when planning airports and managing airport wildlife, especially in areas with high biodiversity (19).

\section{CONCLUSIONS}

1. The mammal fauna of Chisinau airport was represented by 31 species -5 insectivores, 7 bat, 14 rodent, 1 lagomorph, 4 carnivorous species. Most of the mammal species were common or numerous, 7 were rare and 5 species listed in the Red Book of the Republic of Moldova - the bicolour shrew and 4 species of bats.

2. The most abundant and widespread species were 5 rodent species (Microtus arvalis, Apodemus sylvaticus, Apodemus uralensis, Mus musculus, Mus spicilegus) and the fox. On airport territory the most abundant was the field vole, with an average density of 10-15 col./ha, and in adjacent biotopes the wood mouse the most abundant. The fox was the most numerous carnivorous species and its density reached 6 ind./ha in the airport and about 18 ind./ha in adjacent biotopes.

3. The dominant species in little owl's diet was the house mouse with $55 \%$, followed by the field vole with about $24 \%$, and insects with $17 \%$. The Apodemus genus species were found in low proportion.

4. The higher risk for aircraft safety is posed by rodents species that are attractive for prey birds, and by medium sized carnivorous, such as the fox, which can provoke direct damage to the aircraft.

5. Long-term recommendations were developed in order to improve the aircraft flight safety in Chisinau airport.

\section{CONFLICT OF INTERESTS}

No conflict of interests.

\section{REFERENCES}

1. Soldatini C, Albores-Barajas Y.V, Lovato T, Andreon A, Torricelli P, Montemaggiori A. et al. Wildlife strike risk assessment in several Italian Airports: Lessons From BRI And A New Methodology Implementation. PLoS ONE. 2011; 6(12):e28920.

2. DeVault T.L, Kubel J.E, Glista D.J, Rhodes Jr.O.E. Mammalian hazards at small airports in Indiana: impact of perimeter fencing. Human-Wildl. Confl.

\section{AKNOWLEDGEMENTS}

The studies were performed within the grant CŞ-03/2013 and project 20.80009.7007.02 of State Program.

2008;2:240-247.

3. Dolbeer R.A, Wright S.E, Cleary E.C. Ranking the hazard level of wildlife species to aviation using the National Wildlife Strike Database. Wildlife Society Bulletin. 2000;28(2):372-378.

4. Schwarz K.B, Belant J.L, Martin J.A, DeVault T.L, Wang G. Behavioral traits and airport type affect mammal incidents with U.S. civil aircraft. Environ 
ment Management. 2014;54(4):908-18.

5. Baker J.A, Brooks R.J. Raptor and vole populations at an airport. Journal of Wildlife Management. 1981;45:390-396.

6. Barras S.C, Dolbeer R.A, Chipman R.B, Bernhardt G.E. Bird and small mammal use of mowed and unmowed vegetation at John F. Kennedy International Airport, 1998-1999. Proceedings of the Vertebrate Pest Conference 2000. 2000;19:31-36.

7. Washburn B, Bernhardt G, Kutschbach-Brohl L, Commentary. Using dietary analyses to reduce the risk of wildlife-aircraft collisions. HumanWildlife Conflicts. 2011;5(2):204-209.

8. Witmer G.W, Fantinato J.W. Management of rodent populations at airports. Proceedings of the 10th Wildlife Damage Management Conference. 2003;350-358.

9. Popescu A, Murariu D. Fauna României. Mammalia, Rodentia. Editura Academiei Române, Vol. XVI (2), 2001.

10. Pucek Z. Keys to vertebrate of Poland. Mammals. PWN - Polish Scientific Publishers, Warszava, 1981.

11. Red Book of the Republic of Moldova, IIIrd ed. Chișinău „Ştiinţa”, 2015.

12. Thorpe J. Update on fatalities and destroyed civil aircraft due to bird strikes with appendix for 2008; 2009; 2010. Cairns (Australia).

13. Nistreanu V. Mamiferele insectivore (Mammalia: Erinaceomorpha, Soricomorpha) din Republica Moldova. Chişinău: S. n. Tipografia AŞM. 2019.

14. Dibolscaia N, Nistreanu V. Chiropteran species from the ecosystems of Chisinau city. International Simposium „Functională ecology of the animals". Chișinău, 2019;74-76.

15. Tikhonov I, Muntyanu A, Uspenskaya I, Konovalov Yu, Burlaku V, Karaman N. et al. Biotopic distribution, population structure, and some features of small mammal reproduction in Chisinau city. Biology Bulletin. 2012;39(10):839845.

16. Vasilascu N, Nistreanu V, Bogdea L, Postolachi V, Larion A, Caraman N. et al. Diversity and ecological peculiarities of terrestrial vertebrate fauna of Chisinau city, Republic of Moldova. Oltenia Journal for Studies in Natural Sciences. 2013;29(1):219-226.

17. Savin A, Caisîn V, Grosu GH. Dinamica efectivelor și impactul unor prădători în ecosistemele Republicii Moldova. Materialele Simpozionului Internațional dedicate aniversării a 100 ani a academicianului A. Spassky. Chișinău, 2017.

Date of receipt of the manuscript: $27 / 10 / 2021$ Date of acceptance for publication: 28/12/2021

Victoria NISTREANU, ORCID ID: 0000-0002-9726-9684 Alina LARION, ORCID ID: 0000-0002-5313-451
18. Dolbeer R.A, Wright S.E, Weller J.R, Begier M.J. Wildlife strikes to civil aircraft in the United States 1990-2009. Report to the associate administrator for airports, Office of Airport safety and standards, Airport and Safety and Certification, Washington DC, 2015.

19. Novaes W.G, Grossmann N.V, Pimentel D.S, Prada M. Terrestrial mammal and reptile hazards in an airport in the Brazilian Amazon. Human-Wildlife Interactions. 2016;10(1):122-127.

20. Kelly TC, Allan J. Ecological effects of aviation. In: Davenport J, Davenport JL (eds) The ecology of transportation: managing mobility for the environment. Springer, Dordtrecht, 2006.

21. International Civil Aviation Organization. 20082015 Wildlife Strike Analyses (IBIS). Electronic Bulletin. 2017. Available from: https://www.icao. int/safety/IBIS [Accessed 25.10.2021].

22. Allan J. A heuristic risk assessment technique for birdstrike management at airports. Risk Anal. 2006;26(3):723-729.

23. Goszczyński J. Connection between predatory birds and mammals and their prey. Acta Theriol.1977;22: 399-430.

24. Gotta A, Pigozzi G. Trophic niche of the barn owl and Little Owl in a rice field habitat in northern Italy. Ital. J. Zool. 1997;64:55-59.

25. Hounsome T, O'Mahony D, Delahay R. The diet of Little Owls Athene noctua in Gloucestershire, England. Bird Study. 2004;51:3:282-284. doi:10.1080/00063650409461366

26. Laiu L, Murariu D. Diet of the Little Owl (Athene noctua) during summer in a sub-Carpathian depression of Moldovia - Romania. Travaux du Museum National d'Histoire Naturelle 'Grigore Antipa'.1997;37:319-326.

27. Romanowski J. Trophic ecology of Asio otus (L.) and Athene noctua (Scop.) in the suburbs of Warsaw. Pol. Ecol. Stud. 1988;14:223-234.

28. Romanowski J, Altenburg D, Żmihorski M. Seasonal variation in the diet of the little owl, Athene noctua in agricultural landscape of Central Poland. North-Western Journal Of Zoology. 2013; 9(2): 310-318.

29. Kitowski I, Pawlega K. Food Composition of the Little Owl Athene noctua in Farmland Areas of South East Poland. Belg. J. Zool. 2010;140 (2):203211.

30. Zubcov NI. Trophic connections of owls in the biocenoses of Moldova. Ecology of birds and mammals of Moldova. Chisinau "Știința”, 1981;79-94. (In Russian) 